\title{
Physio-biochemical, Quality and Microbial Characteristics: An Analysis of Watermelon Cultivars for the Fresh-Cut Industry
}

\author{
Aminah Myriah Mason ${ }^{1}$, Meijun Yi ${ }^{1}$, Jing Kong ${ }^{1}$, Michael Rickaille ${ }^{2}$, Xingping Yang ${ }^{3}, Z_{h i f a n g ~ Y u}{ }^{1}$, \\ ${ }^{1}$ College of Food Science and Technology, Nanjing Agricultural University, Nanjing, China \\ ${ }^{2}$ College of Agricultural Economics and Management, Nanjing Agricultural University, Nanjing, China \\ ${ }^{3}$ Institute of Vegetables, Jiangsu Academy of Agricultural Sciences, Nanjing, China
}

Email address:

yuzhifang@njau.edu.cn (Zhifang Yu)

${ }^{*}$ Corresponding author

\section{To cite this article:}

Aminah Myriah Mason, Meijun Yi, Jing Kong, Michael Rickaille, Xingping Yang, Zhifang Yu. Physio-biochemical, Quality and Microbial Characteristics: An Analysis of Watermelon Cultivars for the Fresh-Cut Industry. International Journal of Nutrition and Food Sciences.

Vol. 6, No. 4, 2017, pp. 158-166. doi: 10.11648/j.ijnfs.20170604.12

Received: April 11, 2017; Accepted: April 24, 2017; Published: June 7, 2017

\begin{abstract}
Changes in quality, physio-biochemical and microbial characteristics of fresh-cut watermelon of five cultivars widely grown in China (Qilin, Heimeiren, Texiaofeng, 8424 seeded and Jingxin \#1), stored for 5 days at $5^{\circ} \mathrm{C}$ were investigated. High respiration rates and the presence of seed cavities resulted in high juice leakage and weight loss for Jingxin \#1 and 8424 seeded, which also had significant color change after 5 days of storage. Aerobic bacterial count and Total coliform bacteria for all cultivars increased as storage time extended, to less than 5.0 $\log _{10} \mathrm{CFU} / \mathrm{g}$ and $4.0 \log _{10} \mathrm{MPN} / 100 \mathrm{~g}$ respectively with no visible symptoms of decay. The slight changes in quality characteristics (color, firmness, Soluble Solids Content (SSC), $\mathrm{pH}$, juice leakage, weight loss) of fresh-cut Qilin, Heimeiren and Texiaofeng cultivars during storage, suggest that these cultivars are better suited for fresh-cut. Microbial quality, respiration rate, juice leakage and weight loss are key indices in determining the suitability of watermelon cultivars for fresh-cut purposes.
\end{abstract}

Keywords: Watermelon, Fresh-Cut, Characteristics, Quality, Physio-biochemical, Microbial

\section{Introduction}

The high demand and health benefits of watermelon make it a popular fruit for the fresh-cut industry. Watermelon (Citrullus lanatus), is an annual plant of the cucurbitaceous family and one of the world's most widely cultivated crops. It accounts for $6.8 \%$ of the world's area designated to vegetable production [1] and its global consumption exceeds that of any other curcubit [2]. The fruit is enjoyed and consumed fresh globally, in the form of chunks, cubes or slices with or without rind due to its low caloric content, high nutrient levels and thirst-quenching capabilities [3]. Additionally watermelon is rich in phytonutrients including lycopene, a precursor of $\beta$-carotene and is also a rich source of (non-essential) amino acids such as citrulline; an efficient hydroxyl radical scavenger and a strong antioxidant.
Fresh-cut products should offer the advantages of freshness, healthiness, cleanliness, and convenience to the consumer [4], however, the fruits continue all metabolic processes after harvesting and are susceptible to quality deterioration and microbial infestation due to the increased enzymatic activities, transpiration and respiration [5]. Processing of fresh-cut watermelon includes selecting, sanitizing, peeling, slicing and packaging, all of which are aimed at achieving a high quality product. However, damages resulting from cutting not only increase respiration and ethylene production, but also cause an increase in other biochemical reactions responsible for changes in color, flavor and aroma as well as texture and nutritional quality [6].

Good quality fresh-cut produce is characterized by a fresh consistent appearance, acceptable texture and characteristic flavor and aroma, in addition to having a reasonable useful shelf-life to withstand handling throughout the distribution 
and marketing period. This has provided the impetus for much research investigating the shelf-life of specific cultivars of fresh-cut watermelon, suppressing microbial growth and maintaining quality $[7,8]$. Others have reported on the effects of 1- Methylcyclopropene (1-MCP) on metabolism and quality characteristics $[9,10,11,12]$ and on flesh quality and Lycopene stability of fresh-cut watermelon [13]. Evidently, the quality, physio-biochemical and microbial attributes investigated in the literature are important determinants of quality. However these indices vary among cultivars and greater understanding of these indices among the different cultivars is critical for assessing the most suitable cultivars for the fresh-cut market.

Watermelon is an important horticultural crop in China and being the world's largest producer, China accounts for $67 \%$ (73.2 million tons) of global watermelon production (109.6 million tons) [14]. It boasts a wide variety of watermelon cultivars (almost 100 commonly cultivated seeded and seedless cultivars), which coupled with increasing consumer demand for healthier food products, are catalyzing the fresh-cut fruit industry. However, as per our knowledge, these cultivars have remained relatively unexplored and there exists a paucity of information in relation to their suitability for the fresh-cut market. This study therefore investigated the quality, physio-biochemical and microbial changes of five popular cultivars of watermelon to determine their suitability for the fresh-cut industry.

\section{Materials and Methods}

\subsection{Sample Preparation}

During the months of March to July, 2016 freshly harvested fruits of 5 of the most popular watermelon cultivars grown in China, i.e. Qilin, Heimeiren, Texiaofeng (early bearing-March and April), 8424 seeded and Jingxin \#1 (June and July-summer) were purchased from a commercial supplier. Selection of the cultivars depended primarily on market availability. The fruits varied in size and flesh color (red, pink and yellow). Three to five fruits $(15-20 \mathrm{~kg})$ of each cultivar were carefully selected, washed, blotted with paper towels and pre-cooled at $5^{\circ} \mathrm{C}$ degrees for 24 hours. Fruits were peeled, cut longitudinally and then heart and locular flesh portions were cut into $8 \mathrm{~cm}$ slices. Slices from each watermelon were randomly placed into unvented rigid polyethylene storage boxes. The boxes contained 8-10 slices each, weighed (approximately 300-330 g), and were held for 0 , 1,3 , or 5 days at $5^{\circ} \mathrm{C}$. Sample preparation, processing, storage condition and duration simulated the commercial practices for fresh-cut watermelon in China. For analysis of all indices, on each sampling day, 3 replicates per cultivar were used. Sterile work conditions and a temperature of $25^{\circ} \mathrm{C}$ were maintained during sample preparation and throughout the study in accordance with Perkins-Veazie and Collins [13].

\subsection{Analysis of Quality Characteristics}

\subsubsection{Color}

To investigate changes in color, colorimeter measurements were made on days 0 and 5 on five random slices per container replicate using a chromameter with an aperture of $8 \mathrm{~mm}$ diameter, D65 illuminant, and CIE L ${ }^{*} \mathrm{a}^{*} \mathrm{~b}^{*}$ color scale, (Konica Minolta CR400). Calibrations were made using a white color tile. Hue and chroma values were calculated with the formulas $\tan ^{-1} \quad b / a$ and $\left(a^{2}+b^{2}\right)^{1 / 2}$ respectively as described by Perkins-Veazie and Collins [13].

\subsubsection{Firmness}

To evaluate firmness of the samples, a puncture test was used, based on the resistance of selected slices to a pressure applied by a fruit firmness tester (Model 5, Takemura Electric Works, Ltd). During the puncture test, a flat-head stainless steel cylindrical probe (base diameter $5 \mathrm{~mm}$, height $10 \mathrm{~mm}$ ) was used. Three measurements were made and the mean value of each slice was calculated. The firmness of three slices from each container replicate was measured and the results were expressed in Newtons (N) as suggested by Aguayo et al. [15].

\subsubsection{Soluble Solids Content (SSC) and pH}

Samples from each replicate container $(40 \mathrm{~g})$ were blended and then duplicates of $0.5 \mathrm{ml}$ of puree per sample were placed on a hand-held pocket refractometer (Atago, Japan). Results were expressed as \%Brix.

The remainder of the homogenate was used to measure $\mathrm{pH}$ using a $\mathrm{pH}$ meter (Mettler Toledo).

\subsubsection{Weight Loss and Juice Leakage}

Weight loss was determined using a scale (Sartorius Model) with an accuracy of $0.01 \mathrm{~g}$. Fresh weight was monitored before and after storage (days 0 and 5). Losses on the final day of storage were expressed as percentages of the initial fresh weight.

During sample preparation, two sheets of tissue paper were placed at the bottom of the containers marked for juice leakage. Juice that leaked from the watermelon slices during storage was absorbed by the paper and the weight determined using a scale (Sartorius Model) with an accuracy of $0.01 \mathrm{~g}$. The percentage juice leakage was calculated using the formula:

[(container wt+juice wt.)-(container wt.)/(container wt.+fruit wt.)-(container wt.) $]^{*} 100 \%$ as described by Perkins-Veazie and Collins [13].

\subsection{Analysis of Physio-biochemical Characteristics}

\subsubsection{Respiration Rate}

$\mathrm{CO}_{2}$ levels were monitored using 3 samples per cultivar prior to tissue analysis. Watermelon pieces were placed inside $32 \mathrm{~L}$ glass jars which were tightly sealed to avoid leakage. After 30 minutes, $\mathrm{CO}_{2}$ levels were measured by a gas analyzer (PBI Dansensor Checkmate 3 ). The results were expressed as $\mathrm{CO}_{2} \mathrm{mg} \cdot \mathrm{kg}^{-1} \cdot \mathrm{h}^{-1}$. 


\subsubsection{Malondialdehyde (MDA) Determination}

The 2-thiobarbituric acid reaction was used to determine MDA content of fresh-cut watermelon as described by Yuan et al. [16] with slight modifications. Two grams fresh weight of each watermelon sample replicate was homogenized in 6 $\mathrm{ml}$ of $0.25 \% \mathrm{TBA}+10 \% \mathrm{TCA}$. The mixture was transferred to a $10 \mathrm{ml}$ centrifugation tube, heated in a water-bath shaker at $95^{\circ} \mathrm{C}$ for 30 minutes, then quickly cooled in an ice bath. The absorbance was read at $532 \mathrm{~nm}$ after centrifugation at 9000 $\mathrm{rpm}$ for $10 \mathrm{~min}$ at $4^{\circ} \mathrm{C}$ and the value for non-specific absorption at $600 \mathrm{~nm}$ was subtracted. The MDA content was calculated using its extinction coefficient of $155 \mathrm{mM}-1 \mathrm{~cm}-1$ and the amount of MDA expressed as micromole per gram of fresh weight ( $\mu \mathrm{mol} / \mathrm{g} F W)$.

\subsubsection{Peroxidase (POD) Activity}

POD activity was determined according to the method described by Luo et al. [4] with slight modifications. Two grams of each sample replicate was homogenized in $6 \mathrm{ml}$ of Boric acid buffer ( $\mathrm{pH} 8.7$ ). The homogenate was centrifuged at $10000 \mathrm{rpm}$ for $30 \mathrm{~min}$ at $4^{\circ} \mathrm{C}$. After centrifugation, in separate tubes, $2.0 \mathrm{ml}$ Sodium acetate buffer solution (pH5.4) $1.0 \mathrm{ml}$ guaiacol, and $0.05 \mathrm{ml}$ enzyme were added. Finally $0.1 \mathrm{ml} 0.75 \% \mathrm{H}_{2} \mathrm{O}_{2}$ solution was added immediately before the absorbance was read at $460 \mathrm{~nm}$ every 30 seconds for 3 min. At A460 per minute, a change of 0.001 absorbance was defined as 1 unit of enzyme activity and POD activity was expressed as micrograms per minute ( $\mu /$ g.min).

\subsubsection{Superoxide Radical $\left(\mathrm{O}_{2}^{-}\right)$and $\mathrm{H}_{2} \mathrm{O}_{2}$ Content}

$\mathrm{O}_{2}^{-}$content was measured according to the method described by Huan et al. [17] with slight modifications. Two grams of each sample replicate was homogenized in $5 \mathrm{~mL}$ of $50 \mathrm{mM}$ sodium phosphate buffer $(\mathrm{pH} 7.8)$ and centrifuged at $9000 \mathrm{rpm}$ at $4^{\circ} \mathrm{C}$ for $10 \mathrm{~min}$. The incubation mixture contained $1 \mathrm{~mL}$ of $50 \mathrm{mM}$ sodium phosphate buffer $(\mathrm{pH} 7.8)$, $0.1 \mathrm{~mL}$ of $10 \mathrm{mM}$ hydroxyl ammonium chloride and $1 \mathrm{~mL}$ supernatant. After incubation at $25^{\circ} \mathrm{C}$ for $1 \mathrm{~h}, 1 \mathrm{~mL}$ of $17 \mathrm{mM}$ sulphanilic acid and $7 \mathrm{mM}$-naphthyl amine was added separately to the incubation mixture. After reaction at $25^{\circ} \mathrm{C}$ for a further $20 \mathrm{~min}$, the absorbance was read at $530 \mathrm{~nm}$. A standard curve with $\mathrm{NaNO}_{2}$ was used to calculate the $\mathrm{O}_{2}^{-}$ content which was expressed as micromoles per gram of fresh weight ( $\mu \mathrm{mol} / \mathrm{g} \mathrm{FW})$.

To determine $\mathrm{H}_{2} \mathrm{O}_{2}$ content, $2.0 \mathrm{~g}$ of watermelon tissue from each sample replicate was homogenized with $6 \mathrm{ml}$ of $100 \%$ acetone solution. The homogenate was centrifuged at $9000 \mathrm{rpm}$ at $4^{\circ} \mathrm{C}$ for $10 \mathrm{~min}$. The supernatant was collected immediately after for $\mathrm{H}_{2} \mathrm{O}_{2}$ analysis using the Hydrogen Peroxide Assay Kit from Nanjing Jiancheng Bioengineering Institute. $\mathrm{H}_{2} \mathrm{O}_{2}$ content was expressed as micromoles per kilogram of fresh weight $(\mu \mathrm{mol} / \mathrm{Kg} \mathrm{FW})$.

\subsection{Microbial Analysis}

\subsubsection{Enumeration of Aerobic Bacteria}

The aerobic bacterial count of fresh-cut watermelon was evaluated in accordance with the Chinese National Food
Safety Standard for Food Microbiological Examination: Aerobic Plate Count [18]. Random samples of $25 \mathrm{~g}$ of melon pieces from each sample replicate were added to $225 \mathrm{~mL}$ of sterile normal saline and oscillated in an Incubator Shaker (ZH CHENG ZWY 2102C) for $15 \mathrm{~min}$. Upon completion, 10-fold serial dilutions $(1: 10,1: 100,1: 1000,1: 10000)$ of the sample were made in sterile normal saline, as needed, for plating. Two petri dishes were used per dilution and to each dish $1 \mathrm{ml}$ of the corresponding dilution was added. The aerobic plate count was performed by using plate count agar medium incubated at $36^{\circ} \mathrm{C} \pm 1^{\circ} \mathrm{C}$ for $48 \mathrm{~h} \pm 2 \mathrm{~h}$. Microbial counts were reported as colony forming units per gram (CFU/g).

\subsubsection{Enumeration of Coliform Bacteria}

The enumeration of Coliform bacteria was evaluated in accordance with the Chinese National Food Safety Standard for Microbiological Examination of food hygiene: Detection of Coliform bacteria [19]. Random samples of $25 \mathrm{~g}$ of melon pieces from each sample replicate were added to $225 \mathrm{~mL}$ of sterile normal saline and oscillated in an Incubator Shaker (ZH CHENG ZWY 2102C) for 15 min. After shaking, 10 -fold serial dilutions $(1: 10,1: 100,1: 1000,1: 10000)$ of the sample were made in sterile normal saline. Three test tubes of Lactose Bile Fermentation Broth (with an inverted tube) were inoculated with $1 \mathrm{ml}$ for each dilution and cultured at $36^{\circ} \mathrm{C} \pm 1^{\circ} \mathrm{C}$ for $24 \mathrm{~h} \pm 2 \mathrm{~h}$. The Most Probable Number (MPN) of coliforms was determined according to the MPN table and reported as MPN of Coliforms per $100 \mathrm{~g}$ of sample (MPN/100g).

\subsection{Statistical Analysis}

The experiment was conducted in a completely randomized design and SPSS (SPSS Inc., Chicago, USA) was used to perform all statistical analysis. Significant differences between mean values were determined using Tukey's HSD test $(\mathrm{P}<0.05)$ following one-way ANOVA. For comparisons among indices, raw data was used to calculate Pearson correlation coefficients. The significance levels considered for the Pearson correlation were $\mathrm{p}<0.01$ and $\mathrm{p}<0.05$ denoted by $(*)$ and $(* *)$ respectively.

\section{Results and Discussion}

\subsection{Changes in Quality Characteristics}

The appearance of fresh-cut fruits and vegetables is an attribute most immediately obvious to the consumer. More specifically, color is the first quality attribute considered when choosing fresh-cut produce, therefore strongly influencing purchasing decisions [4]. Although color is one of the main quality indicators used by consumers, other factors such as firmness, SSC, juice leakage, weight loss and $\mathrm{pH}$ are also important determinants of fresh-cut fruit quality. 


\subsubsection{Color}

In the present study, $\mathrm{L}^{*}, \mathrm{a}^{*}, \mathrm{~b}^{*}$ and Chroma values for 8424 seeded decreased significantly $(p<0.05)$ on day 5 , however, there was no significant change in color during storage for the Qilin, Heimeiren, Texiaofeng and Jingxin \#1, although an increase in hue was observed for the Heimeiren cultivar (Table 1). These results indicate that the color of these cultivars was maintained and that pigment degradation was very slow throughout storage at low temperature $\left(5^{\circ} \mathrm{C}\right)$. The highest $\mathrm{L}^{*}$ values were recorded for Texiaofeng, a yellow fleshed cultivar and Qilin which is pink-fleshed, indicative of a lighter color. The slight loss of color for most of the cultivars could be attributed to relatively low juice leakage which reduced translucency, and the freshness and overall good quality of the melon fruits used in the study. The results could provide some insight on choosing cultivars for fresh-cut processing based on color as it is perceived that consumers would prefer cultivars with colors of a darker nature or higher saturation and intensity as these are good indicators of lycopene content, maturity and sweetness.

Table 1. Changes in quality characteristics of different watermelon cultivars after cutting on days 0 and 5 of storage at $5^{\circ} \mathrm{C}$.

\begin{tabular}{|c|c|c|c|c|c|c|c|}
\hline \multirow{2}{*}{ Indices } & & \multirow{2}{*}{ Days in Storage } & \multicolumn{5}{|l|}{ Cultivars } \\
\hline & & & Qilin & Heimeiren & Texiaofeng & 8424 seeded & Jingxin \#1 \\
\hline \multirow{10}{*}{ Color } & \multirow{2}{*}{$\mathrm{L}$} & 0 & $41.17 \pm 0.65 a$ & $38.40 \pm 0.99 a$ & $56.16 \pm 2.73 a$ & $38.02 \pm 0.48 \mathrm{a}$ & $35.67 \pm 0.84 a$ \\
\hline & & 5 & $41.52 \pm 0.77 \mathrm{a}$ & $38.71 \pm 0.69 \mathrm{a}$ & $56.15 \pm 1.86 a$ & $31.72 \pm 0.21 \mathrm{~b}$ & $35.61 \pm 1.28 \mathrm{a}$ \\
\hline & \multirow{2}{*}{$\mathrm{a}$} & 0 & $14.42 \pm 0.31 \mathrm{a}$ & $21.75 \pm 0.51 \mathrm{a}$ & $-3.57 \pm 0.52 \mathrm{a}$ & $18.73 \pm 0.62 \mathrm{a}$ & $16.36 \pm 0.45 \mathrm{a}$ \\
\hline & & 5 & $15.01 \pm 0.38 \mathrm{a}$ & $17.80 \pm 1.55 \mathrm{a}$ & $-3.96 \pm 0.22 \mathrm{a}$ & $15.45 \pm 0.43 b$ & $15.30 \pm 0.09 \mathrm{a}$ \\
\hline & \multirow{2}{*}{$\mathrm{b}$} & 0 & $9.37 \pm 0.29 \mathrm{a}$ & $13.93 \pm 0.18 \mathrm{a}$ & $23.15 \pm 1.49 \mathrm{a}$ & $10.90 \pm 0.32 \mathrm{a}$ & $10.50 \pm 0.56 \mathrm{a}$ \\
\hline & & 5 & $9.58 \pm 0.24 \mathrm{a}$ & $12.76 \pm 0.66 \mathrm{a}$ & $23.45 \pm 0.82 \mathrm{a}$ & $9.66 \pm 0.23 b$ & $10.42 \pm 0.15 \mathrm{a}$ \\
\hline & \multirow{2}{*}{ Chroma } & 0 & $17.20 \pm 0.42 \mathrm{a}$ & $25.83 \pm 0.53 \mathrm{a}$ & $23.43 \pm 1.55 \mathrm{a}$ & $21.67 \pm 0.63 \mathrm{a}$ & $19.44 \pm 0.68 \mathrm{a}$ \\
\hline & & 5 & $17.80 \pm 0.44 \mathrm{a}$ & $21.91 \pm 1.64 \mathrm{a}$ & $23.78 \pm 0.82 \mathrm{a}$ & $18.22 \pm 0.48 b$ & $18.52 \pm 0.06 \mathrm{a}$ \\
\hline & \multirow{2}{*}{ Hue } & 0 & $33.02 \pm 0.30 \mathrm{a}$ & $32.66 \pm 0.28 \mathrm{a}$ & $-81.32 \pm 0.82 \mathrm{a}$ & $30.22 \pm 0.76 \mathrm{a}$ & $32.67 \pm 0.64 a$ \\
\hline & & 5 & $32.54 \pm 0.24 \mathrm{a}$ & $35.78 \pm 1.04 \mathrm{~b}$ & $-80.41 \pm 0.50 \mathrm{a}$ & $32.02 \pm 0.31 \mathrm{a}$ & $34.26 \pm 0.49 \mathrm{a}$ \\
\hline \multirow{2}{*}{\multicolumn{2}{|c|}{ Firmness (N) }} & 0 & $3.12 \pm 0.15 \mathrm{a}$ & $5.12 \pm 0.03 \mathrm{a}$ & $3.11 \pm 0.30 \mathrm{a}$ & $3.30 \pm 0.06 \mathrm{a}$ & $3.10 \pm 0.09 \mathrm{a}$ \\
\hline & & 5 & $2.92 \pm 0.47 \mathrm{a}$ & $4.81 \pm 0.23 \mathrm{a}$ & $2.68 \pm 0.19 a$ & $3.23 \pm 0.06 \mathrm{a}$ & $3.37 \pm 0.05 \mathrm{a}$ \\
\hline \multirow{2}{*}{\multicolumn{2}{|c|}{ SSC (\%Brix $)$}} & 0 & $8.42 \pm 0.28 \mathrm{a}$ & $7.30 \pm 0.83 a$ & $7.17 \pm 0.09 a$ & $8.97 \pm 0.52 \mathrm{a}$ & $7.95 \pm 0.28 \mathrm{a}$ \\
\hline & & 5 & $9.57 \pm 0.09 b$ & $7.57 \pm 0.19 a$ & $6.85 \pm 0.76 a$ & $9.00 \pm 0.48 \mathrm{a}$ & $7.33 \pm 0.24 \mathrm{a}$ \\
\hline \multirow{2}{*}{\multicolumn{2}{|c|}{$\mathrm{pH}$}} & 0 & $5.49 \pm 0.07 \mathrm{a}$ & $5.17 \pm 0.13 \mathrm{a}$ & $5.54 \pm 0.03 \mathrm{a}$ & $5.65 \pm 0.09 a$ & $5.56 \pm 0.02 \mathrm{a}$ \\
\hline & & 5 & $5.40 \pm 0.02 \mathrm{a}$ & $5.24 \pm 0.05 \mathrm{a}$ & $5.53 \pm 0.06 \mathrm{a}$ & $5.28 \pm 0.02 b$ & $4.95 \pm 0.02 b$ \\
\hline \multicolumn{2}{|c|}{$\%$ Weight loss } & 5 & 3.00 & 3.77 & 4.32 & 11.46 & 8.84 \\
\hline \multicolumn{2}{|c|}{ \% Juice Leakage } & 5 & 2.94 & 3.64 & 4.07 & 4.76 & 4.48 \\
\hline
\end{tabular}

Note: Values are expressed as means of three replicates \pm SE per cultivar. Within the same index, means ( $n=3$ ) followed by different letters a-b are significantly different by Tukey's HSD $(\alpha=0.05)$

\subsubsection{Firmness}

As shown in Table 1, firmness values for all cultivars tested generally decreased throughout storage, however, these changes were not significant, indicating that firmness for all cultivars was well maintained during storage at low temperature $\left(5^{\circ} \mathrm{C}\right)$. The results are consistent with Gil et al. [20] who reported no differences in firmness of fresh-cut and whole watermelon fruit stored at $5^{\circ} \mathrm{C}$ and $14^{\circ} \mathrm{C}$ over a 9-day storage period. The mean firmness value for Heimeiren (4.62 N) was significantly higher whilst Qilin was significantly lower $(2.98 \mathrm{~N})$ suggesting that there were differences in firmness between cultivars.

An important quality attribute and determinant of shelf-life, firmness can be affected by the presence of cell softening enzymes in fruit tissues, decreased turgor from water loss [21] and increased microbial activity. Watermelon cultivars are likely to differ in texture based on genetic background. During sample preparation and analysis this was evident, with some cultivars being softer whilst others had a crisper texture. From a fresh-cut suitability point of view, firmer cultivars are more favorable for better operational processes.

\subsubsection{Soluble Solids Content (SSC) and pH}

Soluble Solid Content (SSC) measures the sweetness of fruits, a quality that is much sort after by consumers. In the present study, SSC values ranged between $6.85 \%$ and $9.57 \%$ Brix however except for Qilin, which recorded a significant increase on day 5 of storage there were no significant changes in SSC for the other cultivars throughout storage (Table 1). The lack of significant change in SSC is consistent with the findings of Gil et al. [20], Aguayo et al. [22] and Fundo et al. [23] who reported no significant differences in SSC of fresh-cut watermelon fruit and Amarillo melon during storage. The increase in SSC of Qilin could be attributed to the low juice leakage as well as reduced starch or sugar degradation considering the decreasing trend in respiration rate. Qilin and 8424 seeded had significantly higher SSC than the other cultivars, indicating higher sugar content and sweeter flavor. For selecting suitable cultivars for fresh-cut, higher SSC is favorable.

The $\mathrm{pH}$ values the early bearing (spring) cultivars (Qilin, Heimeiren, Texiaofeng) ranged from 5.17 to 5.54, however there were no significant changes throughout storage. In contrast, $\mathrm{pH}$ values of 8424 seeded and Jingxin \#1, the two summer cultivars, decreased significantly on day 5 by $6.5 \%$ and $11 \%$ respectively (Table 1). The decreased values may be a more intermediate product of the TCA cycle during a more active respiration process (as shown in Table 2). The decreasing trend in $\mathrm{pH}$ values during storage observed in this study contrasts the findings of Perkins-Veazie and Collins [13] and Saftner et al. [11]. The different results are likely attributed to differences in cultivars, 
type of cuts, respiration rate of fresh-cut watermelon, storage temperatures and length of storage period.

\subsubsection{Weight Loss and Juice Leakage}

After 5 days of storage, the weight loss for 8424 seeded and Jingxin \#1 were $11.14 \%$ and $8.88 \%$ respectively (Table 1), significantly higher than the other cultivars. Juice leakage for the seedless cultivar Qilin was significantly lower than all other cultivars $(2.94 \%)$, with highest values observed for 8424 seeded (4.76\%) and Jingxin\#1 (4.48\%) during the same period. Greater juice leakage for seeded cultivars has also been reported by Perkins-Veazie and Collins [13]. They attributed the higher values for seeded cultivars to increased tissue degradation associated with seed cavities. The values they reported however were higher than those reported in the present study. This may also be due primarily to differences in watermelon cultivars, storage temperature and duration and type of cuts.

It is evident from the data that juice leakage was the main cause of weight loss, especially for Qilin, Heimeiren and Texiaofeng. A positive relationship $\left(\mathrm{r}=0.78^{* *}\right)$ between weight loss and juice leakage was obtained, suggesting that as juice leakage increased weight loss increased. However, further analysis between juice leakage and texture/firmness revealed no positive relationship, indicating that texture/firmness has no effect on juice leakage, but rather the seed cavities had greater effect as observed in our study and also as reported by Perkins-Veazie and Collins [13].

Since greater weight loss and juice leakage are associated with poor appearance and increased susceptibility to spoilage, these two indices are more important determinants of quality than the other quality characteristics measured in this study. Thus it is suggested that weight loss and juice leakage during storage be minimal for watermelon cultivars selected for fresh-cut processing.

\subsection{Changes in Physio-biochemical Characteristics}

\subsubsection{Respiration Rate}

Respiration rate plays a critical role in postharvest quality of fresh-cut produce. Usually due to the severe disruption of tissues resulting from cutting, fresh-cut processing increases respiration rate, which accelerates tissue degradation leading to quality changes and reduced storage life. In the present study, $\mathrm{CO}_{2}$ values among the tested cultivars varied greatly. Jingxin \#1, a summer cultivar had the highest value recorded (45.06 $\mathrm{CO}_{2} \mathrm{mg} \cdot \mathrm{kg}^{-1} \cdot \mathrm{h}^{-1}$. FW) which is approximately three times that of Qilin - a spring cultivar (14.02 $\mathrm{CO}_{2} \mathrm{mg} \cdot \mathrm{kg}^{-1}$ $\left.\bullet^{-1} . \mathrm{FW}\right)$. The respiration rate of all 5 cultivars decreased gradually and in parallel during the 5 day storage period with the greatest decrease for 8424 seeded (Table 2). The results of the present study, contradict the findings of other authors (Mao et al. [9], Saftner et al. [11], Saftner and Lester [24] who reported increases in $\mathrm{CO}_{2}$ activity in fresh-cut muskmelon and watermelon. The differences between these studies may be attributed to a variety of factors including differences in cultivars, period from cutting to determination, length of storage period and storage temperature as well as the relatively low microbial count of the samples. Saftner and Lester [24] reported that increased respiration rate was associated with the increased microbial populations throughout the later part of their 17 day storage period of muskmelon. Moreover, respiration would be enhanced quickly by mechanical injury such as cutting.

Generally, higher respiration results in accelerated quality deterioration, thus the much higher respiration rates of Jingxin $\# 1$ and 8424 seeded watermelon during the entire storage period indicated that these two cultivars may be more susceptible to quality deterioration than the other cultivars, as evidenced by their high juice leakage and greater change of $\mathrm{pH}$ (Table 1).

Table 2. Changes in physio-biochemical characteristics of different cultivars of fresh-cut watermelon during storage at $5^{\circ} \mathrm{C}$ for 5 days.

\begin{tabular}{|c|c|c|c|c|c|c|}
\hline \multirow[b]{2}{*}{ Cultivar } & \multirow{2}{*}{$\begin{array}{l}\text { Storage } \\
\text { Period (d) }\end{array}$} & \multicolumn{5}{|l|}{ Indices } \\
\hline & & $\begin{array}{l}\text { Respiration Rate } \\
\left(\mathrm{CO}_{2} \mathrm{mg} \mathrm{kg}^{-1} \cdot \mathbf{h}^{-1}\right)\end{array}$ & $\begin{array}{l}\text { MDA } \\
(\mathrm{mmol} / \mathrm{kg} \mathrm{FW})\end{array}$ & $\begin{array}{l}\text { POD } \\
(\mu / \text { g.min })\end{array}$ & $\begin{array}{l}\mathrm{O}_{2}^{-} \\
(\mu \mathrm{mol} / \mathrm{g} \mathrm{FW})\end{array}$ & $\begin{array}{l}\mathrm{H}_{2} \mathrm{O}_{2} \\
(\mu \mathrm{mol} / \mathrm{kg} \mathrm{FW})\end{array}$ \\
\hline \multirow{4}{*}{ Qilin } & 0 & $18.89 \pm 6.89 \mathrm{a}$ & $1.39 \pm 0.07 \mathrm{a}$ & $18.67 \pm 2.33 \mathrm{a}$ & $12.06 \pm 0.72 \mathrm{a}$ & $6.22 \pm 2.11 \mathrm{a}$ \\
\hline & 1 & $19.66 \pm 5.4 \mathrm{a}$ & $1.24 \pm 0.08 \mathrm{a}$ & $48.22 \pm 4.3 b$ & $11.71 \pm 1.16 \mathrm{a}$ & $18.13 \pm 0.48 \mathrm{a}$ \\
\hline & 3 & $8.03 \pm 1.17 \mathrm{a}$ & $1.95 \pm 0.1 b$ & $27.22 \pm 5.10 \mathrm{c}$ & $14.85 \pm 0.71 \mathrm{a}$ & $16.04 \pm 2.74 \mathrm{a}$ \\
\hline & 5 & $9.52 \pm 4.21 \mathrm{a}$ & $2.68 \pm 0.0 \mathrm{c}$ & $30.33 \pm 4.04 \mathrm{ab}$ & $11.52 \pm 1.07 \mathrm{a}$ & $11.06 \pm 4.82 \mathrm{a}$ \\
\hline \multirow{3}{*}{ Heimeiren } & 0 & $25.30 \pm 2.0 \mathrm{a}$ & $1.83 \pm 0.0 \mathrm{a}$ & $13.22 \pm 0.78 \mathrm{a}$ & $10.64 \pm 2.51 \mathrm{a}$ & $7.57 \pm 3.98 \mathrm{a}$ \\
\hline & 3 & $15.50 \pm 2.6 a$ & $2.14 \pm 0.0 \mathrm{~b}$ & $12.44 \pm 2.06 \mathrm{a}$ & $9.66 \pm 0.99 a$ & $11.38 \pm 0.68 \mathrm{ab}$ \\
\hline & 5 & $14.41 \pm 1.1 \mathrm{a}$ & $3.07 \pm 0.0 \mathrm{c}$ & $12.44 \pm 1.16 \mathrm{a}$ & $6.74 \pm 0.41 \mathrm{a}$ & $15.04 \pm 2.51 \mathrm{ab}$ \\
\hline \multirow{4}{*}{ Texiaofeng } & 0 & $33.13 \pm 8.33 \mathrm{a}$ & $1.36 \pm 0.09 \mathrm{a}$ & $123.33 \pm 12.0 \mathrm{a}$ & $10.04 \pm 2.02 \mathrm{a}$ & $5.98 \pm 1.70 \mathrm{a}$ \\
\hline & 1 & $32.41 \pm 7.56 \mathrm{a}$ & $2.85 \pm 0.02 b$ & $94.17 \pm 9.28 \mathrm{ab}$ & $10.75 \pm 2.94 \mathrm{a}$ & $6.01 \pm 0.75 a$ \\
\hline & 3 & $24.44 \pm 0.38 \mathrm{a}$ & $2.65 \pm 0.18 \mathrm{~b}$ & $66.67 \pm 1.67 \mathrm{~b}$ & $13.62 \pm 2.95 \mathrm{a}$ & $7.69 \pm 0.99 a$ \\
\hline & 5 & $25.23 \pm 0.07 \mathrm{a}$ & $2.44 \pm 0.18 b$ & $25.83 \pm 1.67 \mathrm{c}$ & $8.25 \pm 1.13 \mathrm{a}$ & $8.32 \pm 0.48 \mathrm{a}$ \\
\hline \multirow{3}{*}{8424 Seeded } & 0 & $49.75 \pm 0.07 a$ & $2.74 \pm 0.17 \mathrm{a}$ & $5.00 \pm 1.44 \mathrm{a}$ & $11.65 \pm 2.06 \mathrm{a}$ & $8.22 \pm 1.90 \mathrm{a}$ \\
\hline & 1 & $33.10 \pm 8.49 \mathrm{a}$ & $2.49 \pm 0.09 \mathrm{a}$ & $3.33 \pm 0.83 \mathrm{a}$ & $21.75 \pm 1.4 b$ & $11.06 \pm 1.68 \mathrm{ab}$ \\
\hline & 5 & $25.16 \pm 0.04 \mathrm{a}$ & $2.73 \pm 0.04 \mathrm{a}$ & $10.00 \pm 0.00 \mathrm{~b}$ & $14.13 \pm 0.85 \mathrm{a}$ & $25.65 \pm 1.68 \mathrm{c}$ \\
\hline \multirow{4}{*}{ Jingxin \#1 } & 0 & $55.98 \pm 7.96 \mathrm{a}$ & $3.39 \pm 0.08 \mathrm{a}$ & $13.33 \pm 0.83 \mathrm{ab}$ & $11.11 \pm 1.14 \mathrm{a}$ & $17.12 \pm 3.85 \mathrm{ab}$ \\
\hline & 1 & $48.78 \pm 0.19 a$ & $2.99 \pm 0.17 \mathrm{a}$ & $8.33 \pm 0.83 a$ & $8.10 \pm 1.63 a$ & $11.32 \pm 1.15 \mathrm{a}$ \\
\hline & 3 & $41.44 \pm 8.29 \mathrm{a}$ & $3.06 \pm 0.20 \mathrm{a}$ & $7.50 \pm 1.44 \mathrm{a}$ & $15.55 \pm 1.49 \mathrm{a}$ & $11.35 \pm 1.91 \mathrm{~b}$ \\
\hline & 5 & $34.06 \pm 8.50 \mathrm{a}$ & $4.69 \pm 0.23 b$ & $18.33 \pm 3.00 \mathrm{~b}$ & $12.17 \pm 1.03 \mathrm{a}$ & $10.61 \pm 1.31 \mathrm{ab}$ \\
\hline
\end{tabular}

Note: Values are expressed as means of three replicates \pm SE per cultivar. Means $(n=3)$ within the same index followed by different letters (a-c) are significantly different by Tukey's HSD $(\alpha=0.05)$. 


\subsubsection{Malondialdehyde (MDA) Content}

MDA, a naturally occurring organic compound is an end product of lipid peroxidation and an indicator of oxidative stress. It is reactive and potentially mutagenic. Generally, high MDA content indicates faster oxidation process and more severe stress. The results of the study show that MDA values ranged from 1.36 to $4.69 \mathrm{mmol} / \mathrm{kg} \mathrm{FW}$ (Table 2). Cultivars 8424 seeded and Jingxin \#1 had higher MDA content initially, indicating that these cultivars are more susceptible to quality deterioration and are less suitable for fresh-cut. With the exception of 8424 seeded, MDA content increased for all cultivars after 5 days of storage at low temperature $\left(5^{\circ} \mathrm{C}\right)$ (Table 2). An increase in MDA concentration at the end of storage at low temperature $\left(4^{\circ} \mathrm{C}\right)$ was also reported in peach [17].

Despite the effect of lipid peroxidation on plant cells, the results indicate no relationship between juice leakage and lipid peroxidation of the cultivars used in the study although cultivars with the highest amounts of juice leakage (i.e. Jingxin \#1, 8424 seeded, Texiaofeng) had the highest mean MDA content while those with lowest juice leakage (Qilin and Heimeiren) had lowest mean MDA content. The low MDA content recorded for all cultivars in the study is consistent with the findings of Shamberger et al. [25] who found that many fruits and vegetables contain either minute amounts or no MDA.

\subsubsection{Peroxidase (POD) Activity}

Fresh-cut processing results in the disruption of a number of cells, triggering the release of enzymes and their substrates and promotes the increase of oxidative enzyme-catalyzed processes. One such enzyme is POD, which plays an important role in plant defense mechanisms, by catalyzing the reaction that destroys $\mathrm{H}_{2} \mathrm{O}_{2}$. The results clearly show a significant difference in initial POD activity among the 5 cultivars. Texiaofeng had the highest initial POD activity $(123.33 \mu / \mathrm{g} . \mathrm{min})$ and 8424 seeded lowest $(5.00 \mu /$ g.min) (Table 2). After 5 days of storage POD activity of Texiaofeng decreased dramatically to $25.83 \mu / \mathrm{g}$.min while that of 8424 seeded increased significantly to $10 \mu /$ g.min (Table 2 ). Conversely, POD activity of Qilin and Heimeiren increased significantly on day 1, and then gradually decreased. This increase could be attributed to stress resulting from fresh-cut processing supporting the theory of Erkan et al. [26] that fruit exposed to stress conditions, even though showing initial increase, showed a decrease in antioxidant enzymes. Based on the results, POD activity and MDA content showed no synchronous changes during storage.

In processed fruits and vegetables, POD is involved in many deteriorative changes which affect flavor, color, texture and nutritional properties, ultimately resulting in loss of product quality [27]. Thus the increased POD activity observed for 8424 seeded cultivar may have resulted in changes in color during storage.

\subsubsection{Superoxide Anion $\left(\mathrm{O}_{2}^{-}\right)$and Hydrogen Peroxide $\left(\mathrm{H}_{2} \mathrm{O}_{2}\right)$ Content}

In plants, Reactive Oxygen Species (ROS) such as $\mathrm{O}_{2}^{-}$and
$\mathrm{H}_{2} \mathrm{O}_{2}$ are inevitable by-products of normal metabolic processes produced in response to biotic and abiotic stresses [28]. They are widely known for their toxic roles in lipid peroxidation, damage to membranes and in oxidization of protein and DNA, resulting in cell death [29]. As shown in Table $2, \mathrm{O}_{2}{ }^{-}$values ranged from 6.74 to $21.75 \mu \mathrm{mol} / \mathrm{g} \mathrm{FW}^{-} \mathrm{O}_{2}{ }^{-}$ activity for 8424 seeded increased significantly on day 1 , and then gradually decreased. This increase may have been a stress response to the cutting from sample preparation. For all other cultivars there was no statistical difference in $\mathrm{O}_{2}{ }^{-}$ activity throughout the 5 days of storage.

$\mathrm{H}_{2} \mathrm{O}_{2}$ activity varied among cultivars with 8424 seeded recording the highest mean value of $15.33 \mu \mathrm{mol} / \mathrm{kg} \mathrm{FW}$, while 8424 seeded was the only cultivar that showed significant increase in $\mathrm{H}_{2} \mathrm{O}_{2}$ activity on the final day of storage (Table 2). The increase in $\mathrm{H}_{2} \mathrm{O}_{2}$ activity of Heimeiren on day 1 and 8424 seeded on day 5 could be linked to the increased POD activity for both cultivars during the same period, considering the role it plays in the destruction of $\mathrm{H}_{2} \mathrm{O}_{2}$.

Given the relationship between the production of ROS and respiration and their effects on cell degradation and quality deterioration, the increase in $\mathrm{H}_{2} \mathrm{O}_{2}$ activity of 8424 seeded coupled with the high respiration rate (shown in Table 2) may have resulted in higher juice leakage and color changes (shown in Table 1).

Although the changes in the 5 physio-biochemical indices between all cultivars varied, they were within range and showed similar trends during storage, indicating that the influence of fresh-cut processing on these indices was similar. Hence, considering their subsequent role in quality deterioration, the results obtained from these measurements would be very useful for predicting fresh-cut suitability. However, based on the importance of the metabolic pathway and relevant reaction processes for energy and intermediate products, from a postharvest point of view, respiration is the most critical biological process among all the physio-biochemical indices studied. These physio-biochemical changes of fresh-cut produce during storage often lead to increased water and vitamin loss, discoloration, increased microbial activity due to sugars being readily available, reduced SSC, softening and shrinkage. These changes therefore result in quality deterioration and reduced shelf-life.

\subsection{Changes in Microbial Characteristics}

\subsubsection{Aerobic Bacterial Count}

Microbial growth not only limits storage life but also compromises safety. Food Safety is of paramount importance in fresh-cut produce since it does not undergo thermal treatments [7]. The results of the present study show that the aerobic bacterial count of all cultivars increased significantly as storage time increased (Table 3). This is consistent with $\mathrm{J}$. Bai et al, [30] who found that microbial count of fresh-cut honeydew increased as storage time increases. Similar findings were also reported by Aguayo et al, [22], in their study of fresh-cut Amarillo melon. In the present study, mean aerobic bacterial count for the storage period ranged from 
2.84 to $3.83 \log _{10} \mathrm{CFU} / \mathrm{g}$ with values for Jingxin \#1 being significantly lower than other cultivars $\left(2.84 \log _{10} \mathrm{CFU} / \mathrm{g}\right.$ ). No visible symptoms of decay were observed throughout the experiment. This is consistent with the findings of ArtesHernadez et al. [8], who reported no visible symptoms of decay, after 11 days of storage at $5^{\circ} \mathrm{C}$ in their study on UV-C treatment of fresh-cut watermelon.

The Aerobic bacterial count of fresh-cut watermelon in this study was lower than that reported by other authors [7, 30, 10]. Factors such as differences in cultivars, processing operations in relation to type of cuts, packaging, storage temperature and duration may have contributed to the contrasting results. Moreover mean Aerobic bacterial count of all cultivars used in this study were in keeping with the safety limits of food products in China $\left(\log _{10} 4.48 \mathrm{CFU} / \mathrm{g}\right)$.

\subsubsection{Total Coliform Bacteria}

As shown in Table 3, Total coliform bacteria for Jingxin \#1 were significantly higher on day 0 . However for the other cultivars there were no significant changes during storage (Table 3). Mean values for the storage period ranged from 2.70 to $3.45 \log _{10} \mathrm{MPN} / 100 \mathrm{~g}$ with Texiaofeng and 8424 seeded cultivars recording significantly higher means (3.45 and 3.22 $\log _{10} \mathrm{MPN} / 100 \mathrm{~g}$ respectively).

Generally, juice and sugar leakages of fresh-cut produce, foster an environment conducive to microbial growth leading to quality degradation and spoilage, however, this was not the case in the present study indicating that storage at low temperature and storage duration may have had an inhibiting effect on microbial growth.

Table 3. Changes in Aerobic bacterial count and Total coliform bacteria of different cultivars of fresh-cut watermelon during storage at $5^{\circ} \mathrm{C}$ for 5 days.

\begin{tabular}{|c|c|c|c|c|c|c|c|c|}
\hline \multirow{2}{*}{ Cultivar } & \multicolumn{4}{|c|}{ Aerobic bacterial count $\left(\log _{10} \mathrm{CFU} / \mathrm{g}\right)$} & \multicolumn{4}{|c|}{ Total coliform bacteria $\left(\log _{10}\right.$ MPN/100g) } \\
\hline & Day 0 & Day 1 & Day 3 & Day 5 & Day 0 & Day 1 & Day 3 & Day 5 \\
\hline Qilin & $3.29 \pm 0.09 a$ & $3.30 \pm 0.08 \mathrm{a}$ & $3.62 \pm 0.11 \mathrm{a}$ & $4.39 \pm 0.04 b$ & $<2.48 \pm 0.00 \mathrm{nd}$ & $<2.48 \pm 0.00 \mathrm{nd}$ & $<2.48 \pm 0.00 \mathrm{nd}$ & $3.36 \pm 0.00 \mathrm{nd}$ \\
\hline Heimeiren & $3.19 \pm 0.08 \mathrm{a}$ & $3.23 \pm 0.04 \mathrm{a}$ & $3.60 \pm 0.09 \mathrm{~b}$ & $4.09 \pm 0.02 \mathrm{c}$ & $<2.48 \pm 0.00 \mathrm{nd}$ & $<2.48 \pm 0.00 \mathrm{nd}$ & $<2.48 \pm 0.00 \mathrm{nd}$ & $3.36 \pm 0.00 \mathrm{nd}$ \\
\hline Texiaofeng & $3.16 \pm 0.06 \mathrm{a}$ & $3.44 \pm 0.08 \mathrm{ab}$ & $3.86 \pm 0.18 b$ & $4.89 \pm 0.14 \mathrm{c}$ & $3.36 \pm 0.00 \mathrm{a}$ & $3.11 \pm 0.25 \mathrm{a}$ & $3.45 \pm 0.09 \mathrm{a}$ & $3.88 \pm 0.25 \mathrm{a}$ \\
\hline 8424 seeded & $3.47 \pm 0.08 \mathrm{ab}$ & $3.36 \pm 0.11 \mathrm{a}$ & $3.76 \pm 0.15 \mathrm{ab}$ & $3.95 \pm 0.15 b$ & $3.13 \pm 0.15 \mathrm{a}$ & $2.93 \pm 0.25 \mathrm{a}$ & $3.36 \pm 0.00 \mathrm{a}$ & $3.45 \pm 0.90 \mathrm{a}$ \\
\hline Jingxin \#1 & $2.68 \pm 0.02 \mathrm{a}$ & $2.71 \pm 0.07 \mathrm{ab}$ & $2.70 \pm 0.19 \mathrm{ab}$ & $3.26 \pm 0.15 b$ & $3.66 \pm 0.00 \mathrm{a}$ & $2.56 \pm 0.04 b$ & $2.64 \pm 0.16 b$ & $2.56 \pm 0.04 b$ \\
\hline
\end{tabular}

Note: Values are expressed as means of three replicates \pm SE per cultivar. Means $(n=3)$ within an index followed by different letters (a-c) are significantly different by Tukey's HSD $(\alpha=0.05)$. $n d$ indicates that the significant difference could not be calculated.

\subsection{Key Indices for Determining Suitability of Watermelon Cultivars for Fresh-Cut Purposes}

One of the goals of our research is to better understand the relationships among the quality and physio-biochemical and microbial characteristics of fresh-cut watermelon during storage in an effort to determine the indices most important for determining cultivars' suitability for fresh-cut purposes. For the 5 cultivars examined in this study, respiration rate was most highly correlated with juice leakage scores $(\mathrm{r}=0.74 * *)$. Conversely, juice leakage was best correlated with weight loss $\left(\mathrm{r}=0.78^{* *}\right)$ while Aerobic bacterial count was correlated with Total coliform bacteria $\left(\mathrm{r}=0.55^{* *}\right)$ as expected. These results suggest that respiration rate plays a critical role in overall quality characteristics, more specifically juice leakage and color of fresh-cut water melon during storage. Given the importance of food safety, microbial quality (Aerobic bacterial count and Total coliform bacteria) is a key attribute for determining cultivar suitability for fresh cut processing, followed by respiration rate, juice leakage as well as weight loss and color.

\section{Conclusion}

The slight changes in quality and physio-biochemical characteristics recorded for the 5 cultivars used in this study indicate that the quality of fresh-cut watermelon was well maintained after 5 days of storage at $5^{\circ} \mathrm{C}$. Microbial numbers increased synchronously with storage; however total bacterial count was relatively low and as such there were no off-odors or visible symptoms of decay at the end of the storage period. The high respiration rate observed for fresh-cut 8424 seeded and Jingxin \#1, resulted in quality deterioration which led to high juice leakage and weight loss as well as color change of fresh-cut 8424 seeded watermelon. Qilin, Heimeiren, and Texiaofeng cultivars were therefore the most suitable cultivars for fresh-cut watermelon processing.

Given the effect of weight loss and juice leakage on product appearance and susceptibility to spoilage, it is recommended that the amount of both weight loss and juice leakage during storage be minimal when selecting suitable watermelon cultivars for fresh-cut processing. Moreover, microbial quality (Aerobic bacterial count and Total coliform bacteria), juice leakage, respiration rate, weight loss and color proved to be key indices for assessing the suitability of watermelon cultivars for fresh-cut purposes in this study. Overall the results provide useful insight into the watermelon cultivars best suited for fresh-cut processing and for improving product quality of fresh-cut operations.

\section{Acknowledgements}

The authors are grateful to $\mathrm{Na} \mathrm{Cao}$, Xiaoqin $\mathrm{Wu}$, Muyao $\mathrm{Lu}$ and Rui Jiang for their dedicated assistance throughout the experiment. This research was financially supported by the Innovation Project of Jiangsu Agricultural Science (CX(15)1018). 


\section{References}

[1] Gichimu, B, M., Owuor, B, O., Dida, M, M. (2010). Yield of 3 commercial watermelon cultivars in Kenya as compared to a local Landrace. African Journal of Horticultural Science, 3: 24-33.

[2] Guner, N., Wehner, T, C. (2004). The Genes of Watermelon. Horticulture Science 39(6), 1175-1182.

[3] Tarazona-D'iaz, M, P., Viegas, J., Moldao-Martins, M., Aguayo, E. (2011). Bioactive compounds from flesh and by-product of fresh-cut watermelon cultivars. Journal of the Science of Food and Agriculture 91, 805-812.

[4] Luo, H., Jiang, L., Zhang, L., Jiang, J., Yu, Z. (2012). Quality Changes of Whole and Fresh-Cut Zizania latifolia During Refrigerated $\left(1^{\circ} \mathrm{C}\right)$ Storage. Food and Bioprocess Technology 5 , $1411-1415$.

[5] Caleb, O, J., Mahajan, P, V., Al-Said, F, A, J., Opara, U, L. (2013). Modified Atmosphere Packaging Technology of Fresh and Fresh-cut Produce and the Microbial Consequences-A Review. Food and Bioprocess Technology 6, 303-329.

[6] Xisto, A, L, R, P., Vilas Boas, E, V, B., Nunes, E, E., Vilas Boas, B, M., Guerreiro, M, C. (2012). Volatile profile and physical, chemical and biochemical changes in fresh-cut watermelon during storage. Ciência e Tecnologia de Alimentos Campinas, 32(1), 173-178.

[7] Cartaxo, C, B, C., Sargent, S, A., Huber, D, J., Lin, C. (1997). Controlled atmosphere storage suppresses microbial growth on fresh-cut watermelon. Proceedings of Florida State Horticultural Society 110, 252-257.

[8] Artés-Hernández, F., Robles, P, A., Gómez, P, A., Tomás-Callejas, A., Artés, F. (2010). Low UV-C illumination for keeping overall quality of fresh-cut watermelon. Postharvest Biology and Technology 55, 114-120.

[9] Mao, L., Jeong, J., Que, F., Huber, D, J. (2006). Physiological properties of fresh-cut watermelon (Citrullus lanatus) in response to 1-methylcyclopropene and post-processing calcium application. Journal of the Science of Food and Agriculture 86, 46-53.

[10] Zhou, B., McEvoy, J, L., Lou, Y., Saftner, R, A., Feng, H., Beltran, T. (2006). 1-Methylcyclopropene Counteracts Ethylene-Induced Microbial Growth on Fresh-Cut Watermelon. Journal of Food Science-Vol. 71, Nr. 6, M180-M184.

[11] Saftner, R., Luo, Y., McEvoy J., Abbott, J, A., Vinyard, B. (2007). Quality characteristics of fresh-cut watermelon slices from non-treated and 1-methylcyclopropene- and/or ethylene-treated whole fruit. Postharvest Biology and Technology 44, 71-79.

[12] Jiao, Y., Li, W., Zhang, C., Ma, Y., Li, X., Zhao, X. (2011). Effect of 1-Methylcyclopropene treatment on metabolism and qualities of fresh-cut watermelon. Journal of Food Science, 32 (14), 318-322.

[13] Perkins-Veazie, P., Collins, J, K. (2004). Flesh quality and lycopene stability of fresh-cut watermelon. Postharvest Biology and Technology 31, 159-166.

[14] FAO (Food and Agriculture Organization of the United Nations), FAOSTAT agriculture data. [Online] (2013).
Availaible: Retrieved:6/12/2016.

[15] Aguayo, E., Escalona, V, H., Art'es, F. (2004). Metabolic Behavior and Quality Changes of Whole and Fresh Processed Melon. Journal of Food Science-Vol. 69, Nr. 4, SNQ148-155.

[16] Yuan, G, F., Sun, B., Yuan, J., Wang, Q, M. (2010). Effect of 1-Methylcyclopropene on shelf-life, visual quality, antioxidant enzymes and health promoting compounds in broccoli florets. Food Chemistry 118 (3), 774-781.

[17] Huan, C., Jiang, L., An, X., Yu, M., Xu, Y., Ma, R., Yu, Z. (2016). Potential role of reactive oxygen species and antioxidant genes in the regulation of peach fruit development and ripening. Plant Physiology and Biochemistry 104, 294-303.

[18] National food safety standard -Food microbial examination: Aerobic plate count. (2010). GB 4789. 2.

[19] National food safety standard. Microbiological examination of food hygiene- Detection of Coliform bacteria. (2003). GB/T 4789. 3 .

[20] Gil, M, I., Aguayo, E., Kader, A, A. (2006). Quality Changes and Nutrient Retention in Fresh-Cut versus Whole Fruits during Storage. Journal of Agricultural and Food Chemistry 54, 4284-4296.

[21] Beaulieu, J, C., Gorny, J, R. (2001). Fresh-cut Fruits. USDA Handbook 66. Washington D. C, USA

[22] Aguayo, E., Escalona, V, H., Art'es, F. (2008). Effect of hot water treatment and various calcium salts on quality of fresh-cut 'Amarillo' melon. Postharvest Biology and Technology 47, 397-406.

[23] Fundo, J, F., Amaro, A, L., Madureira, A, R., Carvalho, A., Feio, G., Silva, C, L, M., Quintas, M, A, C. (2015). Fresh-cut melon quality during storage: An NMR study of water transverse relaxation time. Journal of Food Engineering 167, 71-76.

[24] Saftner, R, A., Lester, G, E. (2009). Sensory and analytical characteristics of a novel hybrid muskmelon fruit intended for the fresh-cut industry. Postharvest Biology and Technology 51, 327-333.

[25] Shamberger, R, J., Shamberger, B, A., Willis, C, E. (1977). Malonaldehyde content of food. Journal of Nutrition. 107 (8), 1404-1409.

[26] Erkan, M., Wang, S., Wang, C. (2008). Effect of UV treatment on antioxidant capacity, antioxidant enzyme activity and decay in strawberry fruit. Postharvest Biology and Technology 48, 163-171.

[27] Oms-Oliu, G., Odriozola-Serrano, I., Soliva-Fortuny, R., Martı'n-Belloso, O. (2008). The role of peroxidase on the antioxidant potential of fresh-cut 'Piel de Sapo' melon packaged under different modified atmospheres. Food Chemistry 106, 1085-1092.

[28] Dasgupta, N., Biswas, P., Kumar, N., Bera, B., Das, S. (2013). Antioxidants and ROS scavenging ability in ten Darjeeling tea clones may serve as markers for selection of potentially adapted clones against abiotic stress. Physiology and Molecular Biology of Plants 19, 412-433. 
[29] Liu, Z., Wang, X. (2012). Changes in color, antioxidant and free radical scavenging enzyme activity of mushrooms under high oxygen modified atmospheres. Postharvest Biology and Technology. 69, 1-6.
[30] Bai, J., Saftner, R, A., Watada, A, E. (2003). Characteristics of fresh-cut honeydew (Cucumis xmelo L.) available to processors in winter and summer and its quality maintenance by modified atmosphere packaging. Postharvest Biology and Technology 28, 349-359. 